\title{
On the Role of Business Administration in Promoting Economic Development
}

\author{
Chuan-Zhi QIN \\ School of Business Administration, \\ Zhengzhou University of Science and Technology, \\ Zhengzhou, Henan Province P.R., China \\ 807388249@qq.com
}

\begin{abstract}
This paper systematically studies the role of business administration in the adjustment of financial system in China. It focuses on the guiding role of Business administration in economic development. According to the function of business administration, this paper deeply analyzed the important role of the intervention of national means in promoting financial system reform and economic development. Results demonstrate that the perfection and development of market economy itself can be realized by strengthening internal audit, supervision and so on. In addition, because of the important role played by business administration in market access, market entity is effectively supervised and the market economy operates more regulated.
\end{abstract}

Keywords-Business Administration, Management functions, Economic development, Financial

\section{INTRODUCTION}

Economic development requires sound institutional norms, and there are lags and blindness in the economy without institutional norms. Business administration, as a means for the state to regulate economic development, is the basic guarantee for social and political development, and it is of far-reaching significance for building a prosperous and civilized country. At present, economic development presents a trend of globalization, and breakthroughs have also been made in the development of the Belt and Road. World trade is like a big network, linking all walks of life and around the world. Therefore, the contradictions are also prominent in the development and need to be managed and guided by business administration as a powerful regulatory instrument. Business administration is based on the state and uses mandatory laws and regulations as a means to maintain a harmonious environment for economic development and to clear the way for economic development. As a functional guarantee, business administration is based on specific economic development to formulate relevant regulations, rules and regulations, regulate specific economic and trade activities, safeguard national interests, and promote stable and harmonious social and economic development.

\section{OVERVIEW OF THE FUNCTIONS OF BUSINESS ADMINISTRATION}

\section{A. Cultivate market entity energetically}

The administrative department is the main force in maintaining market order. In order to ensure the effective law enforcement of the administrative sector, and promote the stable and sustainable development of the market economy, One of the functions of business administration is to proactively nurture and improve market entities and market systems, to build a collaborative system network between enterprises, enterprises and business administrations, and improve various types of market supervision and enforcement systems.

\section{B. Guarantee the effective implementation of the market economy system}

Business administration plays an important role in restricting and supervising the market economy, it can effectively protect the effective operation of the market order and help to promote the development of market economy and institutional norms. As we all know, the market economy follows a certain law of development that does not follow the human will. However, the effective implementation of the government macro-economic control measures can not only enhance the guarantee for economic development, but also ensure the effective operation of the market economy order. Especially in the background of economic globalization, although the social and economic development of our country has been promoted quickly, it has brought many risks to the economic development of our country at the same time. With the further advancement of the Belt and Road and the continuous development of economic globalization, a sound economic system is needed to ensure the stability and security of China's social economy. As a tool of economic management, business administration can effectively supervise, guide and control the development of market economy [1].

Moreover, there is also need to ensure fair trade, healthy competition and legitimate transactions between buyers and sellers in the market. This not only effectively maintains economic activities, but also creates a sound economic order, which will lay the foundation for promoting the stable development of our economy. 


\section{CharACteristics ANALYSIS OF Business ADMINISTRATION}

\section{A. Business administration is an effective means of administration}

The main feature of business administration is to maintain a market economy with a positive and effective administrative means and create a fair and orderly market environment. This is different from other government administrations without independent funds and projects, whose responsibility is to maintain the law of the development of market economy and create a soft environment conducive to the development of social economy and market. Especially in the rapid economic development of our country today, market entities and interest coverage are integrated, and there is an urgent need for business administration to perform an effective regulatory function with the network of relationships between market development, production, trade and competition is becoming more and more closely knit.

\section{B. Diversified supervision methods of business administration}

Our country seeks truth from facts and Specific analysis should be made for specific problems when supervising and managing the activities of commercial entities. According to the special conditions and social characteristics of our country, the regulatory authorities will take appropriate measures such as administrative punishment or administrative guidance to deal with specific violations of discipline. Fully embodies the concept of humanitarian law enforcement and scientific law enforcement. There are many illegal operations that require the regulation, restriction, and guidance of business administration in the development of the market economy. Only when the means of business administration are implemented, can we ensure the stable and harmonious development of the market economy environment [2].

\section{Broad scope of business administration}

Wide scope is the characteristic of business administration, which is mainly reflected in the application of business administration, which can not only be applied in tangible markets, such as entity operation, internet economy, production market, and so on, but also can be extended to competitive market, conventional market, and even other intangible markets.

\section{Maintaining the interests of consumers is the purpose of business administration}

As an important means of macro-economic Control, business administration, which is also an important support force for the development of all industries, is an indispensable link and plays a role of lubricant in the development of market economy. The fundamental starting point of business administration and the core idea of work is to safeguard the interests of consumers. Only by maintaining the fundamental interests of consumers as the core and regulating the behavior of violating and infringing the rights and interests of consumers, can we really give play to the control function of business administration, promote the orderly development of the market economy, and thus build a harmonious, stable market economy environment [3].

\section{THE PROMOTING EFFECT OF BUSINESS ADMINISTRATION ON CHINA'S ECONOMIC DEVELOPMENT}

\section{A. Regulating the market access rules effectively}

As an important means of maintaining market order, business administration will screen and standardize market participants in accordance with relevant principles, regulations and rules in the course of social and economic development. In the laws and regulations of business administration, the market access rules are set up. Any enterprise, before becomes the market entity, it should accept strict review mechanism, such as registration, examination and approval and so on. With the regulatory function of business administration constantly standardized, strengthened and developed, most of the market entities have been under the supervision. It is the business administration that plays an important role in market access, so that it can effectively supervise the market entity, ensure the standardization of the enterprise, restrain its own business behavior, and ensure the purification of the market economy environment, thus improving the quality of the market subject, building the high quality platform for the market economy activity, encouraging the subject of market to create higher and better economic benefits [4].

\section{B. To play a guiding role in market mechanism}

Business administration is the navigation light of the market subject, which uses mandatory, clear laws, regulations and rules to control the market subject and its market behavior, to ensure a good trading environment for economic activities, and to ensure the stability and harmony of market economy environment, thus promote the development of economic and trade. Business administration can regulate and deal with the subject and phenomenon of violation in time with its perfect reward and punishment system. In addition, business administration is more than just regulatory control, it also mobilizes the power of public opinion to jointly monitor the market, which greatly ensures the legal compliance of commercial behavior and promoted the development of market economy with high efficiency and quality.

\section{Help to promote the development of market economy itself}

Besides standardizing the market subject, business administration can also promote the market economy itself. In the process of social and economic development, the market mechanism regulates and intervene the market behavior and optimize the allocation of resources with its own flexible characteristics. Business administration will intervene and manage the market economy, promote the rational establishment of the market economy system, and thus promote the stable development of the economy according to clear laws and regulations, policies and administrative means

\section{Ensuring the legitimate Rights and interests of consumers}

Consumers are the core of the market economy and the lifeblood of all business activities. The use of mandatory laws and regulations and other means to ensure that the rights and 
interests of consumers are effectively maintained, and that law enforcement is truly for the people. In the specific work, business administration strictly grasps the admittance mechanism from the source, and strictly standardizes and supervises the economic behavior of the market subject in the market operation, and to protect the legal rights and interests of consumers to the maximum extent through definite laws, regulations and administrative penalties[5].

\section{FURTHER PERFECTING THE DESIGN OF BUSINESS ADMINISTRATION}

\section{A. Optimizing the Business Administration system}

A sound business administration system is the cornerstone of ensuring the operation of the market economy. In order to ensure the functions of business administration to all stages and links of the market economy and mobilize the enthusiasm and participation of various administrative departments, we need to establish a department responsibility system, a clear management system, and a more standardized, more scientific and more perfect work system. A good horse with a saddle, a good ship with sails. Only by a strict and perfect system can we have laws, rules and regulations to follow, Only in this way can we strengthen the restriction and management of the system to the economic subject, and avoid management gaps and loose management, eliminate management corruption, thereby effectively helping the market subject and the consumer to avoid the economic risk. It is imperative that Examine the existing business management system, Comb out the complex situations, targeted local reform, further improve and optimize the rules and regulations of the business administration.

Besides more perfect business administration rules and regulations, it also needs to be equipped with a strong and effective implementation force, according to the law, to strengthen the supervision and execution force, to actually put the system policy into place, to realize the maximization of the function of industry and commerce administration.

\section{B. Strengthen internal audit work}

Standardized internal audit plays an important role in the management of departments and units, especially for administrative agencies. Through internal audit, it can effectively promote the formulation and implementation of policies, which is an effective way to promote management through the system. Internal audit not only further standardizes the management system, makes the management work more scientific and systematic, but also can improve the work efficiently and service quality of the administrative department, improve management quality. Therefore, paying attention to the development of internal audit is of great significance to strengthen the function of business administration [6].

Therefore, how to strengthen the internal audit work and make it play a powerful role in market supervision is an urgent problem to be solved. First of all, it is necessary to change the ideological understanding of the personnel of administrative institutions, grasp the ideological guidance, and fully realize the importance of internal audit work; secondly, improve and perfect the internal audit work system, give full play to the role of audit in management work, and improve the efficiency of business administration work.

\section{Strengthen the supervision mechanism and intensity of supervision}

First of all, the improvement of the business administration supervision mechanism needs to put the whole management work under the normative and scientific supervision system, ensure the fair, open and transparent of the business administration, guarantee the implementation of the policy and the timely and effective enforcement of the law. Secondly, we must strengthen the supervision of business administration, and actively build a supervision mechanism of the sector-marketconsumer trinity, strengthen supervision by public opinion, and promote and protect the positive role of business administration in social and economic development.

Business administration needs to play human performance, to mobilize the awareness and enthusiasm of all staff within the mechanism, to encourage every manager to base on the actual position, to actively look for and find problems, feedback and put forward some suggestions for improvement timely. In this way, the efficiency of supervision can be improved, and the function of business administration can be guaranteed fundamentally, institutionally and administratively.

\section{CONCLUSIONS}

Nowadays, the global integration economy has gradually formed; the construction of the Belt and Road is moving towards a beautiful direction, the overall economy of our country is also growing rapidly and steadily. Business Administration needs to play its role in economic activities by using the policies and regulations to further standardize the market economy. Of course, as the mainstay of maintaining market stability, business departments improve their own management mechanisms, strengthen the supervision strength, optimize departmental responsibilities, scientifically, rationally set up management institutions and functional systems, and give full play to the great role of macro-economic control. We should continuously strengthen the effective supervision of business administration on market subjects and market economy and provide strong regulatory protection for the economic and social development.

\section{ACKNOWLEDGEMENTS}

This work was supported by the Association of Social Sciences of Henan Province of China (Grant No.SKL-2018673).

\section{REFERENCES}

[1] SU Jingqin, JIA Yibo The Research Status, Application Prospects and Contextualized Depth of Case Studies of Business Administration in China Chinese Journal of Management , vol. 15(6), pp. 791-802, June 2018.

[2] EISENHARDT K M, GRAEBNER M E. Theory Building from Cases : Opportunities and Challenges Academy of Management Journal, vol. 50(1), pp. 25-32, January 2007

[3] WANG Ting, A Review of the Research and Development on the Case Study Method Based on the Nucleus of CNKI Periodical Literature 
Journal of Wuhan University of Technology(Social Sciences Edition), vol.27(3), pp. 339-444, May 2014.

[4] LIU Yi Peng, Analysis of the role of Business Administration in China undefined Economic Development [J] ECONOMIC \& TRADE, vol.17, pp. 5-6, March 2017.
[5] GONG Mei Rui, The Exploration path of Business Administration function under the background of New normal economy ECONOMIC \& TRADE, vol.17, pp.9-10, March 2017.

[6] SONG Xiao Hui, The role of Industrial and Commercial Administration in the Market economy system CHINA JOURNAL OF COMMERCE vol.26, pp. 93-94, September 2017 